\title{
Methanotrophic symbionts provide carbon for photosynthesis in peat bogs
}

\author{
Ashna A. Raghoebarsing ${ }^{1}$, Alfons J. P. Smolders ${ }^{2}$, Markus C. Schmid ${ }^{1}$, W. Irene C. Rijpstra ${ }^{4}$, \\ Mieke Wolters-Arts ${ }^{3}$, Jan Derksen ${ }^{3}$, Mike S. M. Jetten ${ }^{1}$, Stefan Schouten ${ }^{4}$, Jaap S. Sinninghe Damsté ${ }^{4}$, \\ Leon P. M. Lamers ${ }^{2}$, Jan G. M. Roelofs ${ }^{2}$, Huub J. M. Op den Camp ${ }^{1} \&$ Marc Strous $^{1}$
}

Wetlands are the largest natural source of atmospheric methane ${ }^{1}$, the second most important greenhouse gas ${ }^{2}$. Methane flux to the atmosphere depends strongly on the climate; however, by far the largest part of the methane formed in wetland ecosystems is recycled and does not reach the atmosphere ${ }^{4,5}$. The biogeochemical controls on the efficient oxidation of methane are still poorly understood. Here we show that submerged Sphagnum mosses, the dominant plants in some of these habitats, consume methane through symbiosis with partly endophytic methanotrophic bacteria, leading to highly effective in situ methane recycling. Molecular probes revealed the presence of the bacteria in the hyaline cells of the plant and on stem leaves. Incubation with ${ }^{13} \mathrm{C}$-methane showed rapid in situ oxidation by these bacteria to carbon dioxide, which was subsequently fixed by Sphagnum, as shown by incorporation of ${ }^{13} \mathrm{C}$-methane into plant sterols. In this way, methane acts as a significant (10-15\%) carbon source for Sphagnum. The symbiosis explains both the efficient recycling of methane and the high organic carbon burial in these wetland ecosystems.

Peat bogs alternate between lawns and pools. Lawns are dominated by species that grow up to several decimetres above the water table. Pools are dominated by aquatic species, such as Sphagnum cuspidatum, that form layers of living plants below the water table. We investigated the methane-oxidizing activity of submerged $S$. cuspidatum from peat bog pools at different field locations in the Netherlands, and compared it to the activity of $S$. magellanicum and $S$. papillosum growing in lawns. The potential methane-oxidizing activity was substantially higher in the submerged mosses (Fig. 1). In control experiments with bog water, methane was not oxidized, indicating that the methanotrophic bacteria were mainly present on or in the living Sphagnum tissue.

The identity and location of these methanotrophs was determined in a molecular approach. Total genomic DNA from washed Sphagnum plants was isolated and bacterial 16S ribosomal RNA genes were amplified, cloned into Escherichia coli, sequenced and analysed phylogenetically. One of the 16S rRNA gene sequences of the clone library was affiliated to a cluster of type II methanotrophs that contained acidophilic methanotrophs isolated from Sphagnum bogs, such as Methylocella palustris (identity $93 \%)^{6}$ and Methylocapsa acidiphila (identity $93 \%)^{7}$.

The full 16S rRNA gene sequence was used to design two specific oligonucleotide probes for fluorescence in situ hybridization (FISH). FISH was combined with serial sectioning of the stems and the stem leaves of multiple individuals of submerged S. cuspidatum. The methanotrophic bacterium targeted by the probes was the dominant methanotroph in S. cuspidatum sections, accounting for over $75 \%$ of

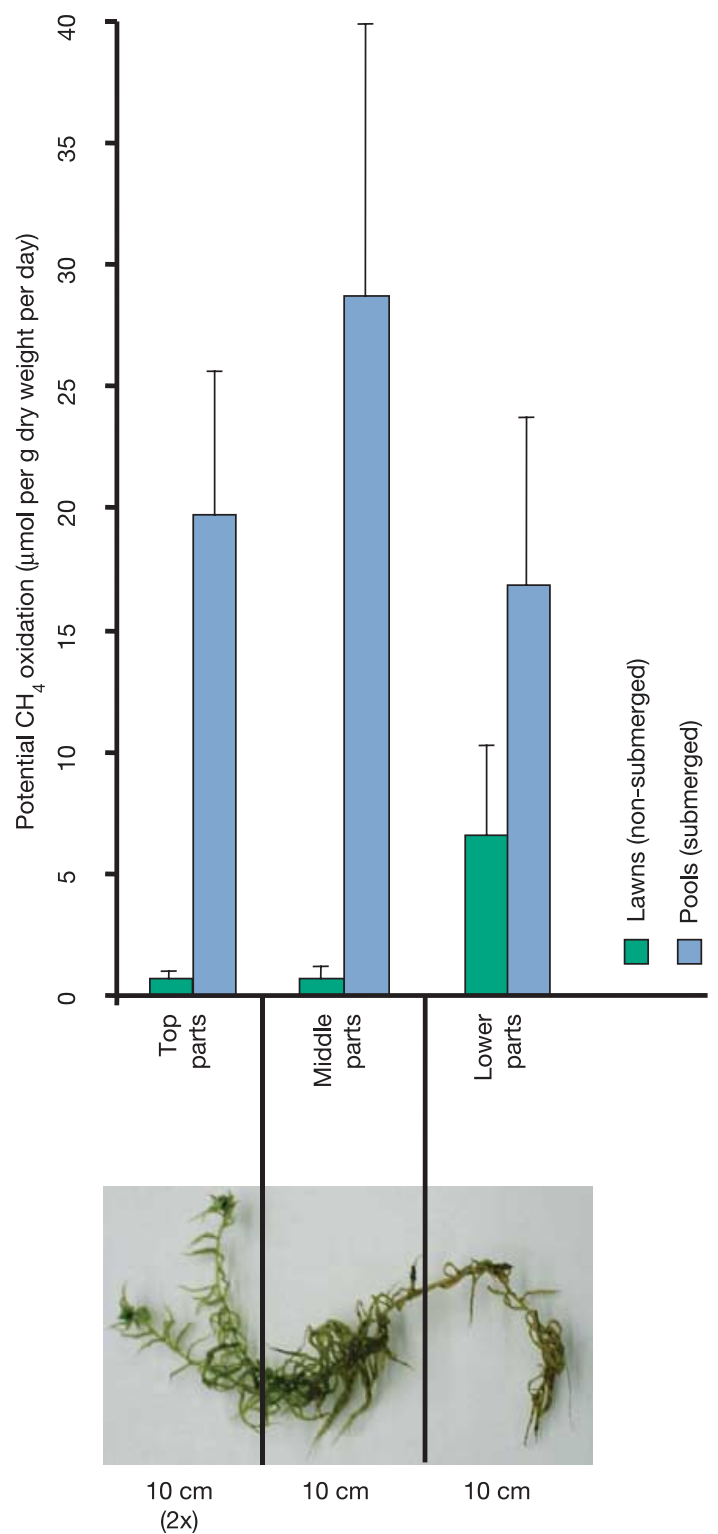

Figure 1 Methane oxidation potential of different parts of submerged and non-submerged Sphagnum mosses as a measure of methanotrophs associated. Error bars indicate standard deviations of at least six independent experiments.

${ }^{1}$ Department of Microbiology, ${ }^{2}$ Department of Aquatic Ecology and Environmental Biology, and ${ }^{3}$ Department of Plant Cell Biology, Radboud University Nijmegen, Toernooiveld 1 6525 ED Nijmegen, The Netherlands. ${ }^{4}$ Royal Netherlands Institute for Sea Research (NIOZ), Department of Marine Biogeochemistry and Toxicology, PO Box 59, 1790 AB Den Burg, The Netherlands. 



Figure 2 | In situ detection of the new methanotroph in S. cuspidatum with fluorescently labelled rRNA-targeted oligonucleotide probes. a, Cryoscanning electron micrograph of a stem cross-section. S, stem leaf; I, outer cortex; II, internal cylinder; III, inner pith. Scale bar, $100 \mu \mathrm{m}$.

b, c, Epifluorescence micrographs of the new methanotroph (purple or pink cells) in the outer cortex of Sphagnum stems, after a double hybridization with the specific probe S-*-18ALF-1437-a-A-18 and the general probe $\mathrm{EUB}^{21}$. Scale bars, 10 and $5 \mu \mathrm{m}$. d, Dense, geometric clusters of the same bacterium on a stem leaf, after a triple hybridization with the specific probe $S^{*}-18$ ALF-1437-a-A-18, the general probe EUB and probe Alf968 (S-Sc-aProt-0968-a-A-18 ( $5^{\prime}$-GGTAAGGTTCTGCGCGTT- $3^{\prime}$ ), specific for $\alpha$-Proteobacteria). Scale bar, $5 \mu \mathrm{m}$. e, Transmission electron micrograph of a geometric cluster closely attached to a stem leaf. Scale bar, $1 \mu \mathrm{m}$.
Table $1 \mid$ Methane and $\mathrm{CO}_{2}$ concentrations and $\delta^{13} \mathrm{C}$ values in the Mariapeel bog pool

\begin{tabular}{lccc}
\hline & $\mathrm{CH}_{4}$ & $\mathrm{CO}_{2}$ & Plants $^{\star}$ \\
\hline Sediment gas composition (\%) & 52 & 48 & - \\
Bulk water concentration $(\mu \mathrm{M})$ & $50 \pm 20$ & $160 \pm 30$ & - \\
$\delta^{13} \mathrm{C}(\% \circ)$ & -56 & -14.5 & -26.5 \\
\hline${ }^{\star}$ The $\delta^{13} \mathrm{C}$ values of growing $(-26 \%$ ) and decaying (-27\%०) & S. cuspidatum were almost \\
identical.
\end{tabular}

all $\alpha$-Proteobacteria. Application of general probes showed that the $\alpha$-Proteobacteria themselves made up $80 \%$ of all detected bacteria, indicating that the new methanotroph was indeed the dominant bacterium in $S$. cuspidatum sections. $\gamma$-Proteobacteria (including type I methanotrophs) were virtually absent.

In S. cuspidatum stems, clusters of the new methanotroph were present in the hyaline cells of the outer cortex (Fig. 2a-c; in total $10^{6}-10^{7}$ methanotrophs per individual plant, total length of stem $\sim 40 \mathrm{~cm}$ ). Hyaline cells are dead, water-filled cells that contain pores by which solutes (and bacteria) can move in or out ${ }^{8}$. The presence of clusters indicated that this bacterium was actively growing inside the hyaline cells. The bacterial clusters consisted of 5-25 individual coccoid cells lying closely together in a random arrangement. On the stem leaves, the same probes hybridized with bacteria occurring as dense, geometric clusters tightly bound to the living plant cells (Fig. 2d, e, $10^{5}-10^{6}$ methanotrophs per individual plant). Differences in the morphology of micro-colonies have been observed to depend on environmental conditions for other microorganisms 9 . On the basis of the measured in vitro methane-oxidizing capacity of S. cuspidatum ( $\sim 20 \mu \mathrm{mol}$ per g dry weight per day; Fig. 1$)$ and the number of methanotrophs per plant, an activity in the order of l-4 fmol methane cell ${ }^{-1} \mathrm{~h}^{-1}$ was estimated for the associated methanotrophs. This is significantly higher than the in vitro methane oxidation rates reported for acidophilic methanotrophs $(\sim 0.3 \mathrm{fmol}$ methane cell ${ }^{-1} \mathrm{~h}^{-1}$ ) (ref. 6), indicating that the actual numbers of methanotrophs per $S$. cuspidatum individual might still be underestimated.

Because FISH analysis had shown that the new methanotroph was the only bacterium occurring in the characteristic geometric clusters, it was possible to identify and inspect this bacterium with transmission electron microscopy (TEM). The TEM and FISH results were consistent with respect to the localization of the methanotroph. TEM also showed that this bacterium did not contain any intracytoplasmic membranes. The absence of intracytoplasmic membranes was noted previously for the phylogenetically related type II methanotroph M. palustris ${ }^{6}$. Otherwise, intracytoplasmic membranes are a characteristic feature of methanotrophic bacteria.

The predominance of type II methanotrophs was further substantiated by the presence of bishomohopanoic acid in Sphagnum lipid extracts after periodic acid treatment. This compound was previously shown to form after periodic acid treatment from the $\mathrm{C}_{35}$ hopanetetrol derivatives, membrane rigidifiers produced by methanotrophic bacteria ${ }^{10}$. The natural ${ }^{13} \mathrm{C}$ contents of this compound $\left(\delta^{13} \mathrm{C}=-39.8 \%\right.$ ) were substantially depleted relative to Sphagnum cell material and enriched compared to that of methane (Table 1), in accordance with its origin from serine-cycle (type II) methanotrophic bacteria ${ }^{11}$. Using this methanotrophic biological marker we were able to determine whether the methanotrophs associated with Sphagnum were actively growing. After incubating Sphagnum with ${ }^{13} \mathrm{C}$-labelled methane for 5 days, isotopic analysis showed that ${ }^{13} \mathrm{C}$-labelled methane was incorporated into this lipid in substantial amounts; nearly $50 \%$ of this lipid was synthesized from the labelled methane, indicating that the methanotrophic population had doubled over the course of the experiment.

The observed tight association of methanotrophic bacteria with S. cuspidatum would enable the efficient recycling into living mosses 


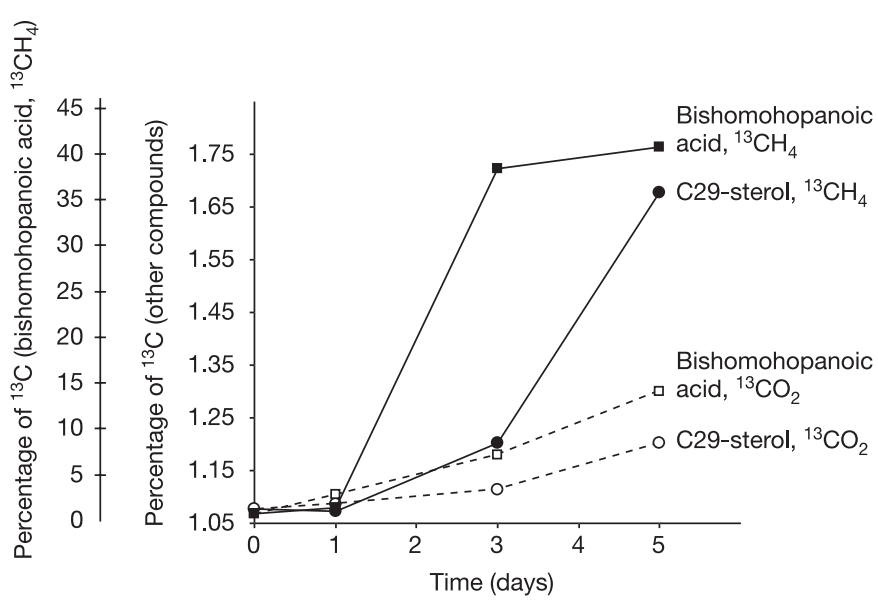

Figure 3 | Incorporation of ${ }^{13} \mathrm{C}$ label in biological markers for Sphagnum (circles) and methanotrophic bacteria (squares). Filled circles/solid lines show the results for labelled methane $\left(99 \%{ }^{13} \mathrm{C}\right)$ in the presence of unlabelled carbon dioxide; open symbols/dashed lines show the results for labelled carbon dioxide $\left(4 \%{ }^{13} \mathrm{C}\right)$.

of both oxygen (derived from photosynthesis) and methane (derived from decaying plants), according to the following set of equations:

$$
\begin{gathered}
\mathrm{CH}_{4} \text { oxidation: } \mathrm{CH}_{4}+2 \mathrm{O}_{2}=\mathrm{CO}_{2}+2 \mathrm{H}_{2} \mathrm{O} \\
\mathrm{CO}_{2} \text { fixation: } 2 \mathrm{CO}_{2}+2 \mathrm{H}_{2} \mathrm{O}=2 \mathrm{CH}_{2} \mathrm{O}+2 \mathrm{O}_{2} \\
\text { Balance: } \mathrm{CH}_{4}+\mathrm{CO}_{2}=2 \mathrm{CH}_{2} \mathrm{O}
\end{gathered}
$$

To provide experimental evidence for this scenario, the potential contribution of methane to carbon fixation by S. cuspidatum was investigated under conditions relevant to the field. Multiple batches of individuals of $S$. cuspidatum were incubated with ${ }^{13} \mathrm{C}$-labelled methane in the presence of unlabelled carbon dioxide. As a control experiment, only ${ }^{13} \mathrm{C}$-labelled carbon dioxide was supplied. Both compounds were added to a final concentration of $0.2 \mathrm{mM}$, close to the in situ concentrations (Table 1). Over 5 days, incorporation of the label by $S$. cuspidatum was determined via the ${ }^{13} \mathrm{C}$ incorporation into sitosterol, a Sphagnum-specific sterol (Fig. 3). Methane was assimilated into the sitosterol pool at a rate of $0.20 \pm 0.03 \mu \mathrm{g} C$ per g dry weight per day, compared to $1.4 \pm 0.1 \mu \mathrm{g} C$ per g dry weight per day for carbon dioxide. Thus, in the presence of carbon dioxide, at near in situ concentrations, the capacity of methane incorporation by $S$. cuspidatum was $\sim 15 \%$ of the carbon dioxide assimilation capacity.

The natural carbon isotope abundances of Sphagnum mosses in the field $\left(\delta^{13} \mathrm{C}-26.5 \%\right.$; Table 1$)$ are consistent with our estimate that $15 \%$ of the carbon fixed by Sphagnum derives from isotopically depleted methane (that is, $-56 \%$; Table 1). S. cuspidatum fixes carbon dioxide via the Calvin cycle, and is able to fractionate strongly against ${ }^{13} \mathrm{C}$ (up to $29 \%$ ) at high carbon dioxide concentrations $(>2 \mathrm{mM})^{12,13}$. However, unlike vascular (semi-)aquatic plants such as rice, $S$. cuspidatum does not have aerenchyma ${ }^{8}$ that facilitate the transport of atmospheric carbon dioxide. Therefore, at lower carbon dioxide concentrations, carbon assimilation by $S$. cuspidatum is limited by mass transfer, and carbon fractionation has been reported to decrease to at most $4 \%$ (refs 12,13 ). Because the average carbon dioxide concentration in the field was approximately $0.16 \mathrm{mM}$, a range of $4-10 \%$ was used as a conservative estimate for carbon fractionation by $S$. cuspidatum in the field ${ }^{12,13}$. With this assumption, the data from Table 1 and a simple isotopic mass balance (see Methods), we calculated that methane contributed on average between $5 \%$ and $20 \%$ to the carbon fixed by S. cuspidatum in the field, in good agreement with the labelling results. It is likely that variation in local conditions (water depth, exposure to wind, temperature, light availability, rates of methane ebullition compared to diffusion/advection) will affect the relative contribution of methane to the carbon uptake of Sphagnum mosses in space and time. This will also be determined by the location of the symbiotic methanotrophs in the plants, both in the direct vicinity of the photosynthetically active cells and in the more remote hyaline cells of the stems.

Our results show that methane is a significant and as yet overlooked supplement to the carbon intake of submerged S. cuspidatum in peat bogs. Peat bogs in the Northern Hemisphere store up to onethird of the carbon sequestered in soils globally ${ }^{14}$. This is surprising considering that the primary production is limited by the nutrient delivery through rain water and the limited delivery of carbon dioxide to the acidic waters of these ecosystems ${ }^{5}$. The efficient recycling of peat decomposition products (such as methane) as demonstrated here may mechanistically explain the paradox of peatlands as ecosystems with apparent low primary productivity combined with high carbon burial.

\section{METHODS}

In situ conditions. In the Mariapeel nature reserve (the Netherlands: $51^{\circ} 24^{\prime} 90^{\prime \prime}$ $\left.\mathrm{N} ; 5^{\circ} 54^{\prime} 90^{\prime \prime} \mathrm{E}\right), \delta^{13} \mathrm{C}$ values of Sphagnum mosses and material from the decaying peat were determined on freeze-dried homogenized material as described previously ${ }^{15}$. Concentrations and $\delta^{13} \mathrm{C}$ values of dissolved carbon dioxide and methane were measured as described previously ${ }^{16}$.

Methane oxidation. Potential methane oxidation of different parts of Sphagnum were measured by incubating $6 \mathrm{~g}$ of thoroughly washed Sphagnum in $100 \mathrm{ml}$ infusion flasks sealed with airtight rubber stoppers. To prevent mass transport limitations, no additional water was added to the experiments. To each flask $1 \mathrm{ml}$ of pure methane was added and methane consumption was measured every $6 \mathrm{~h}$ over 2 days. Methane oxidation rates were calculated by linear regression. Tenfold concentrated water samples $\left(10^{6}\right.$ bacterial cells $\left.\mathrm{ml}^{-1}\right)$ from the bog were used as controls and showed no methane oxidation. Samples were collected in the Netherlands from seven lawn locations (S. magellanicum, S. papillosum) and six bog pools (S. cuspidatum), one of these being the Mariapeel. Methane was measured on an HP 5890 gas chromatograph equipped with a flame ionization detector and a Porapak Q column (80/100 mesh).

$16 \mathrm{~S}$ rRNA gene sequence analysis, FISH and electron microscopy. Total genomic DNA from S. cuspidatum plants containing methanotrophs, isolated with combined methods ${ }^{17}$, was used as template for PCR amplification of $16 \mathrm{~S}$ rRNA genes. PCR was performed with general bacterial primers ${ }^{18}$ using a T gradient thermal cycler (Biometra), and a clone library was made as described previously ${ }^{18}$. Based on the obtained 16S rRNA gene sequences, two new oligonucleotide probes S-*-18ALF-0218-a-A-18 (5'-GGGCCGATCCCCC GGCGA- ${ }^{\prime}$ ) and S- ${ }^{*}-18$ ALF-1437-a-A-18 (5'-CTTGCGGTTAACAGAACG- $3^{\prime}$ ) were designed using the ARB program package ${ }^{19}$. Apart from these speciesspecific probes we used group-specific probes described previously $y^{20,21}$. Fresh S. cuspidatum stems sectioned with a scalpel (section thickness $0.1 \pm 0.05 \mathrm{~mm}$ ) were used for FISH as described previously ${ }^{22}$. Formamide concentrations used in the FISH experiments varied between $10 \%$ and $20 \%$. No signal was obtained at these formamide concentrations when testing the specificity of the probes with Beijerinckia indica ssp. indica (DSM 1715), which has the fewest mismatches of all reference organisms to the designed probes. Electron microscopy (TEM/ SEM) was performed on stems and stem leaves following published proto$\mathrm{cols}^{6,22}$.

Methane incorporation measurements. S. cuspidatum, collected from the Mariapeel nature reserve, was washed with demineralized water and incubated in $250-\mathrm{ml}$ serum bottles in $5 \mathrm{~g}$ wet weight aliquots with $150 \mathrm{ml}$ medium as described previously ${ }^{8} .{ }^{13} \mathrm{C}$ - or ${ }^{12} \mathrm{C}_{-} \mathrm{CH}_{4}$ or $\mathrm{CO}_{2}$ were added to final concentrations of $200 \mu \mathrm{M}$ as specified in the text. The bottles were shaken at 150 r.p.m. at ambient conditions and sacrificed for lipid analysis at days 0 , 1,3 and 5 . Lipids were ultrasonically extracted and analysed by gas chromatography/mass spectrometry and isotope ratio gas chromatography mass spectrometry as described ${ }^{23}$. Hopanes were analysed by treatment of the lipid fraction with periodic acid and sodium borohydride as described previously ${ }^{10,24}$.

Isotopic mass balancing. The measured $\delta^{13} \mathrm{C}$ values of S. cuspidatum in the field $(-26 \%$, see Table 1$)$ resulted from assimilation of dissolved carbon dioxide $(-14.5 \%)$, respired methane $(-56 \%)$ and fractionation against ${ }^{13} \mathrm{C}$ during (mass-transfer-limited) carbon dioxide fixation ${ }^{12,13}(7 \pm 3 \%$ ). The following equation describes this relationship quantitatively (where $a$ denotes the fraction of plant carbon derived from methane and Ep denotes the fractionation during 
fixation):

$$
\begin{gathered}
\delta^{13} \mathrm{C}(\text { Sphagnum })=a \delta \delta^{13} \mathrm{C} \text { (respired methane) } \\
+(1-a) \delta \delta^{13} \mathrm{C} \text { (carbon dioxide) }-E p
\end{gathered}
$$

Because all $\delta^{13} \mathrm{C}$ values from equation (4) were known experimentally, it could be derived that the contribution of methane to Sphagnum carbon $(a)$ was between 0.05 and 0.2 (equivalent to $5-20 \%$ ).

\section{Received 23 December 2004; accepted 9 May 2005.}

1. Hein, R., Crutzen, P. J. \& Heimann, M. An inverse modeling approach to investigate the global atmospheric methane cycle. Global Biogeochem. Cycles 11, 43-76 (1997).

2. Rodhe, H. A comparison of the contribution of various gases to the greenhouse effect. Science 248, 1217-1219 (1990).

3. Smith, L. C. et al. Siberian peatlands a net carbon sink and global methane source since the early Holocene. Science 303, 353-356 (2004)

4. Dedysh, S. N. et al. Isolation of acidophilic methane-oxidizing bacteria from northern peat wetlands. Science 282, 281-284 (1998).

5. Lamers, L. P. M., Farhoush, C., Van Groenendael, J. M. \& Roelofs, J. G. M. Calcareous groundwater raises bogs; the concept of ombrotrophy revisited. J. Ecol. 87, 639-648 (1999).

6. Dedysh, S. N. et al. Methylocella palustris gen. nov., sp. nov., a new methaneoxidizing acidophilic bacterium from peat bogs, representing a novel subtype of serine-pathway methanotrophs. Int. J. Syst. Evol. Microbiol. 50, 955-969 (2000).

7. Dedysh, S. N. et al. Methylocapsa acidophila gen. nov., sp. nov., a novel methane-oxidizing and dinitrogen fixing acidophilic bacterium from Sphagnum bog. Int. J. Syst. Evol. Microbiol. 52, 251-261 (2002)

8. Rydin, H. \& Clymo, R. S. Transport of carbon and phosphorus compounds about Sphagnum. Proc. R. Soc. Lond. 237, 63-84 (1989)

9. Yao, R., Macario, A. J. L. \& Conway de Macario, E. Immunochemical differences among Methanosarcina mazei S-6 morphologic forms. J. Bacteriol. 174, 4683-4688 (1992).

10. Rohmer, M., Bisseret, P. \& Neunlist, S. in Biological Markers in Sediments and Petroleum (eds Moldowan, J. M., Albrecht, P. \& Philp, R. P.) 1-17 (Prentice Hall, London, 1992).

11. Jahnke, L. L., Summons, R. E., Hope, J. M. \& Des Marais, D. J. Carbon isotopic fractionation in lipids from methanotrophic bacteria II: The effects of physiology and environmental parameters on the biosynthesis and isotopic signatures of biomarkers. Geochim. Cosmochim. Acta 63, 79-93 (1999).

12. Keeley, J. E. \& Sandquist, D. R. Carbon: freshwater plants. Plant Cell Environ. 15, 1021-1035 (1992).

13. Smolders, A. J. P., Tomassen, H. B. M., van Mullekom, M., Lamers, L. P. M. \& Roelofs, J. G. M. Mechanisms involved in the re-establishment of
Sphagnum-dominated vegetation in rewetted bog remnants. Wetlands Ecol. Manag. 11, 403-418 (2003)

14. Post, W. M., Emanuel, W. R., Zinke, P. J. \& Strangenberger, A. G. Soil carbon pools and world life zones. Nature 298, 156 (1982).

15. Marguillier, S., van der Velde, G., Dehairs, F., Hemminga, M. A. \& Rajagopal, S Trophic relationship in an interlinked mangrove-seagrass ecosystem as traced by $\delta^{13} \mathrm{C}$ and $\delta^{15} \mathrm{~N}$. Mar. Ecol. Prog. Ser. 151, 115-121 (1997).

16. Smolders, A. J. P., Tomassen, H. B. M., Lamers, L. P. M., Lomans, B. P. \& Roelofs, J. G. M. Peat bog restoration by floating raft formation: the effects of groundwater and peat quality. J. Appl. Ecol. 39, 391-401 (2002).

17. Lomans, B. P. et al. Microbial populations involved in cycling of dimethyl sulfide and methanethiol in freshwater sediments. Appl. Environ. Microbiol. 67, 1044-1051 (2001).

18. Juretschko, S. et al. Combined molecular and conventional analyses of nitrifying bacterium diversity in activated sludge: Nitrosococcus mobilis and Nitrospira-like bacteria as dominant populations. Appl. Environ. Microbiol. 64, 3042-3051 (1998).

19. Ludwig, W. et al. ARB: A software environment for sequence data. Nucleic Acids Res. 32, 1363-1371 (2004).

20. Amann, R. I. et al. Combination of $16 \mathrm{~S}$ rRNA-targeted oligonucleotide probes with flow cytometry for analyzing mixed microbial populations. Appl. Environ. Microbiol. 56, 1919-1925 (1990).

21. Daims, H., Bruhl, A., Amann, R., Schleifer, K. H. \& Wagner, M. The domainspecific probe EUB338 is insufficient for the detection of all Bacteria: development and evaluation of a more comprehensive probe set. Syst. Appl. Microbiol. 22, 434-444 (1999).

22. Wolters-Arts, M. et al. Water-conducting properties of lipids during pollen hydration. Plant Cell Environ. 25, 513-519 (2002).

23. Schouten, S. et al. Biosynthetic effects on the stable carbon isotopic compositions of algal lipids: Implications for deciphering the carbon isotopic biomarker record. Geochim. Cosmochim. Acta 62, 1397-1406 (1998).

24. Sinninghe Damsté, J. S. et al. The occurrence of hopanoids in planctomycetes: implications for the sedimentary biomarker record. Organic Geochim. 35, 561-566 (2004).

Acknowledgements We thank K. T. van de Pas-Schoonen, A. Pol, H. P. M. Geurts, J. Eygensteyn, M. van Mullekom, J. Berk, H. Tomassen and M. M. A. van Herpen for technical support. Part of this study was supported by the Dutch Ministry of Agriculture, Nature Management and Food quality (Research Program 'Overlevingsplan Bos en Natuur')

Author Information The 16S rRNA gene sequences were deposited at GenBank under accession number AY163571. Reprints and permissions information is available at npg.nature.com/reprintsandpermissions. The authors declare no competing financial interests. Correspondence and requests for materials should be addressed to A.J.P.S. (a.smolders@science.ru.nl) or J.S.S.D.

(damste@nioz.nl). 